\title{
Sylvestre le chat ? Aliments et perception du "sauvage" en Basse Andalousie
}

Dominique Fournier

\section{(2) OpenEdition}

12 Journals

Édition électronique

URL : https://journals.openedition.org/tc/479

DOI : $10.4000 /$ tc. 479

ISSN : 1952-420X

Éditeur

Éditions de l'EHESS

Édition imprimée

Date de publication : 1 octobre 1996

ISSN : 0248-6016

Référence électronique

Dominique Fournier, "Sylvestre le chat ? Aliments et perception du "sauvage" en Basse Andalousie », Techniques \& Culture [En ligne], 27 | 1996, mis en ligne le 28 octobre 2005, consulté le 29 septembre 2022. URL : http://journals.openedition.org/tc/479 ; DOI : https://doi.org/10.4000/tc.479

Ce document a été généré automatiquement le 29 septembre 2022.

Tous droits réservés 
Sylvestre le chat? Aliments et perception du "sauvage" en Basse Andalousie

Dominique Fournier 